\title{
SURVEI TELUR CACING PADA KOTORAN KUKU DAN PERSONAL HYGIENE PENJAMAH MAKANAN WARUNG TEGAL (Warteg) DI KOTA TEGAL TAHUN 2016
}

\author{
Diah Ayu Ningtiyas ${ }^{1)}$, Sugeng Abdullah ${ }^{2)}$ \\ Jurusan Kesehatan Lingkungan, Politeknik Kesehatan Kemenkes Semarang, \\ Jl. Raya Baturaden KM 12 Purwokerto, Indonesia
}

\begin{abstract}
Abstrak
Di kota Tegal Warteg diminati oleh banyak konsumen. Penjamah makanan berpotensi menularkan penyakit salah satunya penyakit kecacingan, oleh karena itu perlu dilakukan pemeriksaan telur cacing pada penjamah makanan. Penelitian ini adalah penelitian survey yang bersifat deskriptif. Hasil yang diperoleh menunjukan bahwa Personal Hygiene penjamah makanan Warteg di kota Tegal adalah tidak baik. Tidak ditemukan telur cacing pada kotoran kuku penjamah makanan dan jenis telur cacing pada kotoran kuku penjamah makanan Warteg di kota Tegal. Disimpulkan bahwa Personal Hygiene penjamah makanan Warteg di kota Tegal tidak baik tetapi tidak ditemukan telur cacing pada kotoran kuku dan jenis telur cacing penjamah makanan Warteg di kota Tegal.
\end{abstract}

Kata kunci : Telur cacing, Kuku, Personal Hygiene dan Penjamah Makanan

\section{PENDAHULUAN}

Menurut Undang-undang Republik Indonesia Nomer 36 Tahun 2009 tentang Kesehatan, pasal 162 menyebutkan bahwa upaya kesehatan lingkungan ditujukan untuk mewujudkan kualitas lingkungan yang sehat, baik fisik, kimia, biologi, maupun sosial serta memungkinkan setiap orang mencapai derajat kesehatan setinggi-tingginya(Depkes RI, 2009).

Personal Hygiene adalah suatu usaha pemeliharaan kesehatan diri seseorang yang bertujuan mencegah terjangkitnya penyakit serta untuk memperbaiki status kesehatanya. Salah satu indikator dari Personal Hygiene adalah perawatan kaki, tangan dan kuku (Perry dan Potter, 2005).

Kuku yang panjang dan tidak terawat akan menjadi tempat melekatnya berbagai kotoran yang mengandung berbagai bahan dan mikroorganisme di antaranya bakteri dan telur cacing. Penularan cacingan diantaranya melalui tangan yang kotor. Kuku jari tangan yang kotor yang kemungkinan terselip telur cacing akan tertelan ketika makan, hal ini di perparah lagi apabila tidak terbiasa mencuci tangan memakai sabun sebelum makan (Luize , 2004 dan Onggowaluyo, 2002).

Di Indonesia angka nasional prevalensi kecacingan pada tahun 1987 sebesar 78,6\%, data prevalensi penyakit kecacingan di Indonesia pada tahun 2002-2006 secara berurutan adalah sebesar $33,3 \%, \quad 33,0 \%, \quad 46,8 \%, \quad 28,4 \%$, dan $32,6 \%$. Sedangkan prevalensi infeksi cacaing tambang secara berurutan pada tahun 2002 sampai 2006 sebesar 2,4\%, 0,6\%, 5,1\%, 1,6\%, dan 1,0\% (Depkes RI, 2006).

Berdasarkan hal tersebut peneliti tertarik untuk melakukan penelitian dengan judul "Survei Telur Cacing Pada Kotoran Kuku Dan Personal Hygiene

1) Email : diahayuningtiyas53@yahoo.com

2) Email : sugengzend2016@gmail.com
Pengamatan awal oleh penulis, bahwa di beberapa kota (kota Tegal, kota Purwokerto, kota Jakarta dan lain-lain) banyak ditemukan warungwarung tradisional disebut warteg (warung Tegal). Hal yang sama di jumpai pula di kota Tegal. Di kota Tegal warung jenis ini tersebar hampir semua di seluruh wilayah kota. Warung Tegal merupakan jenis pelayanan non pajak maka dari itu pada Dinas Koperasi UMKM Perindustrian dan Perdagangan kota Tegal tidak menyediakan data warteg, sama halnya dengan Pemerintah Daerah yang lainya tidak ada data tentang warteg.

Tujuan penelitian ini yaitu sebagai berikut :

1. Tujuan Umum

Mengetahui adanya telur cacing pada kotoran kuku penjamah makanan pada warung Tegal (warteg) di kota Tegal tahun 2016.

2. Tujuan khusus

1) Mendeskripsikan Personal Hygiene (kebersihan kuku, rambut, tangan, mulut, kebersihan baju khusus/seragam karyawan) penjamah makanan dan aspek kebersihan kuku pada warung Tegal (warteg) di kota Tegal tahun 2016.

2) Memeriksa adanya telur cacing pada kotoran kuku penjamah makanan pada warung Tegal (warteg) di kota Tegal tahun 2016.

3) Menentukan jenis telur cacing yang ada pada kotoran kuku penjamah makanan pada warung Tegal (warteg) di kota Tegal tahun 2016.

\section{METODE PENELITIAN}

Jenis penelitian ini adalah penelitian survei yang bersifat deskriptif. Penelitian deskriptif dimaksudkan untuk mengetahui secara kualitas ada tidaknya pencemaran telur cacing usus (Soil 
Transmitted Helminth) pada kuku penjamah makanan di warung Tegal (warteg) kota Tegal tahun 2016. (Sudarwan Danim, 2003:52).

kriteria warteg tertentu yaitu :

1. Letak warteg di pinggir jalan raya (tidak masuk gang)

2. Warteg banyak pengunjung yang makan dengan kapasitas tempat duduk yang tersedia (tempat duduk model kursi panjang >3 kursi)

3. Menyediakan banyak jenis lauk pauk yang di hidangkan (lebih dari 7 jenis)

4. Harga makanan yang relatif murah (harga berbeda dengan makanan rumah makan yang lain)

5. Terdapat plang/tanda tulisan warung Tegal (warteg) di depan bangunan/warung

6. Apabila dalam 1 kecamatan ditemukan lebih dari 1 warteg dan masuk dalam 5 kreriteria diatas maka ditentukan menggunakan sampel ramdom pilih yang paling dekat.

Kriteria penjamah makanan yaitu

1. Penjamah makanan bersedia diambil sampel kukunya

2. Penjamah makanan bersedia untuk di wawancara/ diberi pertanyaan oleh peneliti

3. Penjamah makanan bersedia menjawab pertanyaan dengan jujur.

Data hasil penelitian yang telah diperoleh, selanjutnya dianalisis dengan menggunakan analisis tabel.

\section{HASIL DAN PEMBAHASAN}

\section{Letak Geografi Kota Tegal}

Kota Tegal secara geografis terletak pada posisi 10908' - 109¹0’ Bujur Timur dan 0650' - 0653' Lintang Selatan. Dimana secara administrative letak kota Tegal berbatasan langsung dengan Kabupaten Brebes di sebelah barat, dengan Kabupaten Tegal di sebelah timur dan selatan, sementara sebelah utara dengan Laut Jawa. Luas wilayah kota Tegal relative kecil, yaitu 39,68 km². Jumlah penduduk kota Tegal tahun 2014 berdasarkan data dari Badan Pusat Statistik kota Tegal sebanyak 244.998 jiwa,Jadi Kota Tegal merupakan kota padat penduduk.Kota Tegal memiliki 4 kecamatan yaitu kecamatan Tegal Timur dengan luas wilayah 6,36 $\mathrm{km}^{2}$, kecamatan Tegal Barat luas wilayah $15,13 \mathrm{~km}^{2}$, kecamatan Tegal Selatan luas wilayah $6,43 \mathrm{~km}^{2}$, dan kecamatan Margadana 11,76 km².

\section{Letak Warteg}

Kecamatan Tegal Timur salah satunya yaitu di Kelurahan Mangkukusuman, dengan nama Warteg "Warteg Cucak Rowo". Warteg tersebut terletak di Jl. Kaloran, Kelurahan Mangkukusuman, Tegal Timur, tepat dijalan utama menuju pasar tradisional kota Tegal. Warteg Cucak Rowo merupakan lokasi yang strategis di tengah-tengah pusat kota, dekat dengan ramainya orang-orang yang berjualan maupun pengunjung pasar tradisional kota Tegal, juga terletak di jalan raya. Kecamatan Tegal Barat salah satunya yaitu di Kelurahan Debong Lor, dengan nama Warteg "Warteg Ibu Supri”. Warteg tersebut terletak di Jl. Gatot Subroto, Kelurahan Debong Lor, Tegal Barat, tepat di depan jalan utama menuju Pantura kota Tegal, merupakan lokasi yang strategis di tengah-tengah pusat kota, dekat dengan jalan utama menuju pantura kota Tegal, juga terletak di jalan raya. Kecamatan Tegal Selatan salah satunya yaitu di Kelurahan Bandung, dengan nama Warteg "Warteg Barokah". Warteg tersebut terletak di Jl. Citiroh, Kelurahan Bandung, Tegal Selatan, Warteg Barokah merupakan lokasi yang strategis, dekat dengan ramainya orang-orang yang berjualan maupun pengunjung pasar tradisional, sekolah, lapangan maupun kantor-kantor pemerintahan daerah, juga terletak di jalan raya. Kecamatan Margadana salah satunya yaitu di Kelurahan Sumurpangang, dengan nama Warteg "Warteg Pak Yono”. Warteg tersebut terletak di Jl. Wahidin, Kelurahan Sumurpanggang, Margadana, Warteg Pak Yono merupakan lokasi yang strategis di jalur pantura Tegal arah kota Brebes, dekat dengan jalur kendaraan umum maupun pribadiyang lalu lalang tempat supir beristirahat di warteg tersebut, kebanyakan pelangganya adalah supir angkot, supir bus, tukang becak dll.

\section{Keadaan Warteg}

Jauh dari tempat pembuangan sampah (TPS) sekitar 10m lebih dari warung, lantai terbuat dari ubin bersih tidak licin, dan kedap air, dinding bersih, rata, kokoh dan mudah di bersihkan, terdapat langitlangit, pencahayaan berupa alami dengan adanya jendela dengan ukuran 1 x $1 \mathrm{~m}$ ditambah dengan 2 pintu di sebelah kanan dan kiri, sirkulasi udara lancar dan adanya kipas angin yang diletakan di atas atas langit-langit, terdapat tempat sampah yang disediakan hanya memanfaatkan ember bekas, dan tas bekas belanjaan kedap air dan tidak terdapat tutup, terdapat 4 kursi dengan model kursi panjang dengan kapasitas hingga 4-5 orang pengunjung dengan kontruksi kuat dan bersih, terdapat 3 buah meja yang kuat, bersih, warna terang, bersih dan tidak rusak, dan terdapat etalase untuk menaruh lauk yang siap saji dengan keadaan etalase terdapat tutup, tidak ada serangga, warna terang dan makanan terpisah.Tempat sampah yang memenuhi syarat meliputi terbuat dari bahan kedap air, tidak mudah berkarat, mempunyai tutup, dan memakai kantong plastik khusus untuk sisa bahan makanan, disediakan tempat pengumpulan sementara yang terlindung dari serangga, tikus dan hewan lainnya dan terletak yang mudah dijangkau oleh kendaraan pengangkut sampah.

\section{Hasil Penelitian Karakteristik Responden}




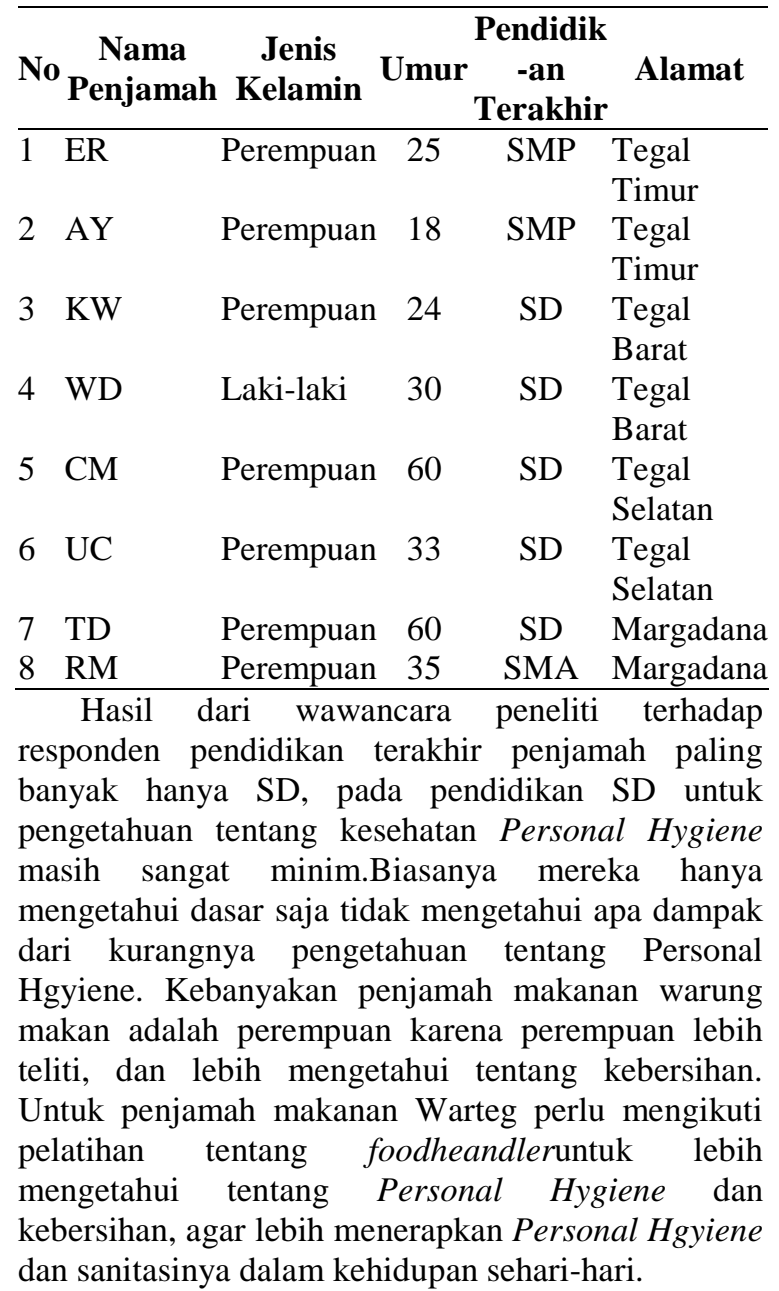

Personal Hygiene

Aspek Kebersihan Personal Hygiene

\begin{tabular}{llccc}
\hline No $\quad$ Item & Baik & $\begin{array}{c}\text { Tidak } \\
\text { Baik }\end{array}$ & Jumlah \\
\hline 1 & Kebersihan tangan & 8 & 0 & 8 \\
2 & Kebersihan kuku & 8 & 0 & 8 \\
3 & Kebersihan rambut & 7 & 1 & 8 \\
4 & Kebersihan mulut & 0 & 8 & 8 \\
5 & Kebersihan baju kerja & 0 & 8 & 8
\end{tabular}

karyawan

Hasil tidak baik, karena ada item seperti kebersihan mulut, kebersihan rambut dan kebersihan baju kerja karyawan yang tidak baik.

\begin{tabular}{|c|c|c|c|c|}
\hline No & $\begin{array}{c}\text { Kegiatan Personal } \\
\text { Hygiene }\end{array}$ & Baik & $\begin{array}{l}\text { Tidak } \\
\text { Baik } \\
\end{array}$ & Jumlah \\
\hline 1 & $\begin{array}{l}\text { Mencuci tangan } \\
\text { setelah kegiatan luar }\end{array}$ & 8 & 0 & 8 \\
\hline 2 & $\begin{array}{l}\text { Mencuci tangan } \\
\text { dalam sehari }\end{array}$ & 8 & 0 & 8 \\
\hline 3 & $\begin{array}{l}\text { Memotong kuku } \\
\text { dalam } 1 \text { minggu }\end{array}$ & 8 & 0 & 8 \\
\hline 4 & $\begin{array}{l}\text { Keramas dalam } 1 \\
\text { minggu }\end{array}$ & 8 & 0 & 8 \\
\hline 5 & $\begin{array}{l}\text { Gatal-gatal pada } \\
\text { rambut }\end{array}$ & 8 & 0 & 8 \\
\hline
\end{tabular}

$\begin{array}{lllll}6 & \text { Merokok } & 7 & 1 & 8\end{array}$

$\begin{array}{lllll}7 & \text { Seragam kerja } & 0 & 8 & 8\end{array}$

Merokok kategori Peronal Hgyiene tidak baik yaitu ada 1 orang penjamah makanan yang merokok tetapi pada saat pengolahan makanan tidak merokok. Seragam kerja kategori Personal Hygiene tidak baik yaitu semua penjamah makanan di semua Warteg yang diteliti tidak menggunakan seragam kerja.

Selama pengolahan makanan penjamahharus memakai pakaian kerja dan dalam keadaan bersih, pakaian kerja yang tidak terjaga kebersihanya justru bisa menjadi media tumbuhnya kuman dan menyebabkan kontaminasi pada makanan. Oleh karena itu sebaiknya penjamah makanan memakai pakaian kerja khusus yang bersih.

\section{Pemeriksaan Kotoran Kuku}

\begin{tabular}{|c|c|c|c|}
\hline No Nama & $\begin{array}{c}\text { Hasil } \\
\text { Pemeriksaan }\end{array}$ & $\begin{array}{l}\text { Jenis Telur } \\
\text { Cacing }\end{array}$ & Keterangan \\
\hline $1 \mathrm{ER}$ & Negatif & - & - \\
\hline $2 \mathrm{AY}$ & Negatif & - & - \\
\hline $3 \mathrm{KW}$ & Negatif & - & - \\
\hline $4 \mathrm{WD}$ & Negatif & - & - \\
\hline $5 \mathrm{CM}$ & Negatif & - & - \\
\hline $6 \mathrm{UC}$ & Negatif & - & - \\
\hline $7 \mathrm{TD}$ & Negatif & - & - \\
\hline $8 \mathrm{RM}$ & Negatif & - & - \\
\hline
\end{tabular}

Personal Hygiene didapatkan hasil tidak memenuhi syarat, tetapi pemeliharaan kebersihan tangannya sangat bagus.Seperti kukunya tidak panjang dan tidak kotor.Meskipun tidak menggunakan seragam kerja karyawan tetapi penjamah makanan menggunakan pakaian yang bersih dan terawat.Mencuci tangan sebelum dan sesudah melaksanakan kegiatan maupun dari berpergian menggunakan sabun menjadi rutinitas penjamah makanan.Kondisi sebagaimana disebutkan diatas, sehingga keberadaan telur cacing tidak ada di dalam kuku penjamah makanan.

Jenis Telur Cacing

\begin{tabular}{clc}
\hline No & Jenis Telur Cacing & Jumlah \\
\hline 1 & Ascaris lumbricoides & 0 \\
2 & Ancylostoma & 0 \\
3 & Trichuris trichiura & 0 \\
4 & Enterobius vemicularis & 0 \\
\hline & Jumlah & 0 \\
\hline
\end{tabular}
makanan Warteg adalah Negatif atau tidak ditemukan telur cacing pada kotoran tersebut. Hal ini menujukkan bahwa pada kotoran kuku di 8 penjamah makanan Warteg kota Tegal tidak ditemukan satupun jenis telur cacing. Faktor yang menyebabkan tidak adanya telur cacing pada kotoran kuku penjamah makanan adalah penjamah makanan sudah menerapkan Personal Hygiene, seperti unsur Personal Hygiene memotong kuku minimal 1 kali dalam seminggu, mencuci tangan apabila setelah bepergian dari luar, dan mencuci tangan sebelum 
mengolah makanan sudah diterapkan dengan baik pada kehidupan seharai-hari penjamah.

Penjamah makanan harus menjaga dan lebih meningkatkan lagi dalam masalah Personal Hygiene agar tetap sehat.

\section{SIMPULAN DAN SARAN}

\section{Simpulan}

Personal Hygiene (kebersihan kuku, rambut, tangan, mulut, baju khusus/seragam karyawan) penjamah makanan Warteg di kota Tegal termasuk dalam kategori Tidak Baik.Tidak ditemukan telur cacing pada kotoran kuku penjamah makanan Warteg di kota Tegal.Jenis telur cacing pada kotoran kuku penjamah makanan Warteg di kota Tegal tidakdiketahui karena tidak ditemukan adanya telur cacing.

\section{Saran}

Menerapkan/ melaksanakan Personal Hygiene secara paripurna/ sempurna, khususnya menggunakan penutup mulut, menggunakan seragam kerja karyawan dan tidak merokok. Melakukan pemeriksaan kesehatan secara berkala. Melengkapi sarana sanitasi yang belum ada, seperti tempat sampah yang memenuhi syarat kesehatan. Perlu adanya penelitian lebih lanjut tentang pemeriksaan telur cacing dan Personal Hygiene pada penjamah makanan Warteg.

\section{DAFTAR PUSTAKA}

Anwar, at.al, 1998, Pedoman Bidang Studi Makanan dan Minuman, Jakarta: Pusat Pendidikan Tenaga Kesehatan Depkes.

Anwar, dkk. 1992. Pedoman Bidang Studi Sanitasi Makanan Dan Minuman Pada Institusi Pendidikan Tenaga Sanitasi. Jakarta : Proyek Pengembangan Pendidikan Tenaga Sanitasi Pusat.

Aris Santjaka, 2011. Statistik Untuk Penelitian Kesehatan. Yogyakarta : Muha Medik.

Danim, Sudarwan. 2003. Riset Keperawatan : Sejarah \& Metodologi. Jakarta : EGC.
Djuanda, Adhi. 2007. Ilmu Penyakit Kulit dan Kelamin FKUI,Edisi Kelima. Jakarta : FKUI.

Entjang, I., 2001. Mikrobiologi dan Parasitologi Untuk Akademi Keperawatan. Bandung : PT. Citra Aditya Bakti.

Hay RJ, Moore MK. Mycology. In: Burns T, Breathnach S, Cox N, GriffithsC, editors. Rook's Textbook of Dermatology. 7 thed. UK: BlackwellPublishing; 2004.

Husein M, Hassab-El-Naby M, Shaheen IMI, Abdo HM, El-Shafey HAM.Comparative studyfor the reliability of potassium hydroxide mount versusnail clipping biopsy in diagnosis of onychomycosis. The Gulf Journal ofDermatology and Venerology.

Isro'in \& Andarmoyo, (2012), Personal Hygiene : Konsep, Proses dan Aplikasi dalam praktekkeprawatan, edisi pertama, Yogyakarta : Graha Ilmu.

Onggowaluyo, J. S., 2002. Parasitologi Medik l,Jakarta : EGC.

Perry \& Potter, 2005, Buku Ajaran Fundamenta Kepratan : Konsep, Proses\&Praktek, edisi 4 vol I. Jakarta : EGC.

Peter J. Hotes, 2003, Soil Transmitted Helminth Infection : The Nature Causes and Burdenof the Condition, WHO : Department of Microbiology and Tropical Medicine the George Washington University.

Srisasi Gandahusada, 1998, Parasitologi Kedokteran, edisi ketiga, Balai PenerbitJakarta : FKUI.

Tri Cahyono, 2014, Pedoman Penulisan Proposal Penelitian dan Karya Tulis Ilmiah Edisi Revisi Ketiga, Purwokerto : Kementerian Kesehatan RI Politeknik Kesehatan Depkes Semarang Jurusan Kesehatan Lingkungan. 